\title{
$\begin{array}{llllllllllllllll}\mathbf{S} & \mathbf{T} & \mathbf{U} & \mathbf{D} & \mathbf{I} & \mathbf{A} & \mathbf{I} & \mathbf{M} & \mathbf{A} & \mathbf{T} & \mathbf{E} & \mathbf{R} & \mathbf{I} & \mathbf{A} & \mathbf{L} & \mathbf{Y}\end{array}$
}

KWARTALNIK HISTORII KULTURY MATERIALNEJ 68 (3), 2020

PL ISSN 0023-5881

www.iaepan.edu.pl the CC BY 4.0 license (https://creativecommons.org/licenses/by/4.0/)

DOI: 10.23858/KHKM68.2020.3.001

\author{
Karol Kollinger
}

\section{Stan i historia badań nad pucharkiem szklanym znalezionym w grobie kobiecym w Kryłosie (druga połowa XII w.)}

\begin{abstract}
Słowa kluczowe: szkło, naczynie, Ruś, Halicz, Kryłos, Wyszogród, Jarosław Ośmiomysł Key words: glass, vessel, Ruthenia, Halych, Krylos, Vyshhorod, Yaroslav Osmomysl
\end{abstract}

I. Okoliczności i kontekst odkrycia. II. Historia rekonstrukcji.

III. Dalsze losy kryłoskiego naczynia. IV. Wnioski

W artykule przedstawiono wyniki badań nad okolicznościami i kontekstem odkrycia w Kryłosie pucharka szklanego oraz nad historią rekonstrukcji jego kształtu. Kierując się poglądem, że „historia problemu jest zawsze częścią jego rozwiązania”, nie ograniczono się do zaprezentowania stanu badań. Rozpoznano, jaką drogę rozważań obrano w literaturze przedmiotu, w jaki sposób korzystano z osiągnięć poprzedników i z jakich podstaw źródłowych czerpali badacze, tworząc swoje narracje. Podjęty temat stał się pretekstem do prześledzenia na tym konkretnym przykładzie jak tworzona była wiedza i wyobrażenia na temat przeszłości, gdy stawano wobec pozostałości materialnych oraz braku dokumentacji z wykopalisk, a często także zaginięcia lub zniszczenia części zabytków. Intencją autora było także wykazanie, jak ważne może być pojedyncze znalezisko dla szerzej zakrojonych badań nad dziejami Rusi².

\section{Okoliczności i kontekst odkrycia}

Dnia 25 lipca 1936 r. we wsi Kryłos (rejon halicki, obwód iwanofrankowski), kilkanaście metrów na wschód od nowożytnej cerkwi parafialnej Zaśnięcia Przenajświętszej Bogarodzicy, natrafiono na fundamenty halickiego soboru katedralnego. Ich odkrywanie kontynuowano w roku następnym. Wykopaliska prowadziła ekspedycja zorganizowana przez Towarzystwo Naukowe im. Tarasa Szewczenki, pod kierownictwem Jarosława Pasternaka (1892-1969), od 1928 r. dyrektora Muzeum Towarzystwa, a finansowal je arcybiskup metropolita lwowski i halicki Andrzej Szeptycki (1865-1944) ${ }^{3}$. Od tego czasu w Kryłosie, 6 km na południe od współczesnego miasta Halicza, lokalizuje się Halicz wczesnośredniowieczny (ryc. 1) ${ }^{4}$.

1 Cetwiński M. 2017, s. 391.

2 Za uwagi do tekstu serdecznie dziękuję prof. Władysławowi Duczce oraz mgr Sylwii Jędrzejewskiej.

3 Pasternak Â. 1937a, s. VII n.; Pasternak Â. 1937b, s. 4 n.; Pasternak Â. 1938, s. 59 n.; Pasternak Â. 1944, s. 82-126; Bandrìvs'kij M., Lukoms'kij Û., Sulik R. 1993, s. 395-397; Bandrìvs'kij M. 2005, s. 129-130; Bandrìvs'kij M. 2015, s. 93-95; Gavrilûk O. 2010, s. 16; Baran V. 2016, s. 174-177; zob. też Chudzik D. 2014 , s. 43 n.

${ }^{4}$ O sporze dotyczącym jego lokalizacji, poprzedzającym odkrycie z 1937 r., zob.: Pasternak Â. 1937a, s. II-VII; Pasternak Â. 1938, s. 57-59; Bandrìvs'kij M., Lukoms'kij Û., Sulik R. 1993, s. 394-395; Baran V. 2016, s. 172-174. 
Odnaleziona w takich okolicznościach halicka świątynia po raz pierwszy została wspomniana jako cerkiew Świętej Bogarodzicy, w związku ze wzmianką o pochowaniu w niej w 1187 r. księcia halickiego Jarosława Ośmiomysła ${ }^{5}$. Część badaczy datuje początek jej budowy już na koniec pierwszej połowy XII w. ${ }^{6}$

W lipcu 1937 r. w zachodnim, frontowym przedsionku soboru, w którym było główne wejście, $10 \mathrm{~cm}$ poniżej, jak uznano, spalonej, prawdopodobnie drewnianej podłogi, odkryto kamienny sarkofag ${ }^{7}$. Znajdowały się w nim przemieszane kości, tworzące prawie kompletny szkielet 50-60-letniego mężczyzny. Ponieważ nie stwierdzono żadnych śladów odzieży, obuwia lub ozdób, założono, że zmarły został ograbiony ${ }^{8} .25 \mathrm{~cm}$ na wschód od sarkofagu, $60 \mathrm{~cm}$ pod podłogą (?), odkryto szkielet kobiety — „ułożony bezpośrednio w ziemi, kiedyś może w trumnie drewnianej”, którego dolna część została zniszczona przez znacznie późniejszą jamę, wypełnioną kawałkami cegły ${ }^{9}$. Wiek zmarłej na podstawie stanu uzębienia Jarosław Chmilews'kyj (1895-1965) szacował na 18-20 lat ${ }^{10}$, zaś w wyniku późniejszych analiz wskazano na 16-23 lata $^{11}$. Uznano, że w sarkofagu złożono Jarosława Ośmiomysła (zm. w 1187 r.) $)^{12}$, a w przypadku kobiety postawiono hipotezę, że mogła to być jego córka, o której brak wzmianek w źródłach ${ }^{13}$. Na terenie świątyni nie stwierdzono wówczas śladów innych grobów ${ }^{14}$.

Syntetyczna monografia, będąca zbiorem ówczesnych ustaleń na temat Halicza wczesnośredniowiecznego, ukazała się drukiem w 1944 r. w działającym pod nadzorem władz niemieckich Wydawnictwie Ukraińskim Kraków-Lwów ${ }^{15}$. Pasternak przemilczał w niej dalsze losy kości tych dwóch osób. Odnaleziono je przypadkowo w listopadzie 1991 r. w trakcie prac archeologicznych w krypcie soboru św. Jura we Lwowie, w skrzynce z dykty. Znajdowała się w niej również szklana butelka z kartką w środku, na której zapisano datę 31 sierpnia $1939 \mathrm{r}$. i informacje, podpisane przez Pasternaka, że są to odkryte w Kryłosie szczątki Jarosława Ośmiomysła $^{16}$. W tym też soborze znajduje się dziś grób księcia. W literaturze wspomina się, że w skrzynce znajdowały się kości należące do dwóch osób ${ }^{17}$.

Wielu badaczy jest przekonanych, że w Kryłosie odnaleziono miejsce pochówku właśnie Jarosława $^{18}$. Przypuszczenie, że obok księcia pochowano jego córkę, legło zaś u podstaw kolejnych stawianych hipotez. W przedsionku halickiej świątyni miałaby spocząć nieznana nam skądinąd córka Ośmiomysła i jego kochanki, Nastazji Czagrówny ${ }^{19}$ lub matka Mścisława Mści-

5 Ipat'evskaâ lìtopis'. 1908, szp. 656.

${ }^{6}$ Zob. ostatnio: Mel'nik V., Bornâk U. 2019, s. 104, por.: Kostruba 1939; Pasternak Â. 1944, s. 120 n.; Pasternak Â. 1978, s. 75 .

7 Zob. szerzej: Pasternak Â. 1944, s. 132; por.: Pasternak Â. 1937a, s. XVII; Pasternak Â. 1938, s. 63; Bandrìvs'kij M., Lukoms'kij Û., Sulik R. 1993, s. 397-399; Bandrìvs'kij M. 2005, s. 130.

8 Pasternak Â. 1944, s. 132.

9 Pasternak Â. 1938, s. 64; Pasternak Â. 1944, s. 139.

10 Za: Pasternak Â. 1937a, s. XVIII, przyp. 55. W późniejszej pracy Pasternak podał natomiast, że wiek ten wskazał antropolog, A. Czortkower (za: Pasternak Â. 1958, s. 10). Chodzi najpewniej o Salomona Czortkowera, który zginął w $1943 \mathrm{r}$.

11 Gorbenko S. 1996, s. 93-94.

12 Pasternak Â. 1944, s. 110, 133-134, 140; zob. też Pasternak Â. 1978, s. 75, 79.

13 Pasternak Â. 1944, s. 140.

14 Pasternak Â. 1944, s. 133.

15 Kubìjovič V. 1985, s. 170; zob. też: Pan'kìvs'kij K. 1965, s. 116-118; szerzej na ten temat: Hryciuk G. 1995, s. 56-57, 65; Golovata L. 2013, s. 157 n.; Matwijów M. 2015.

16 Bandrìvs'kij M., Lukoms'kij Û., Sulik R. 1993, s. 400-405.

17 Zob.: Gorbenko S. 1996, s. 11 n.

18 Np.: Dąbrowski D. 2002, s. 28; Kostikk M. 2013, s. 4-5, 60-62; Golembjovs'ka-Tobìaš A., Dombrovs'kij D. 2019 , s. 29.

19 Tomenčuk B. 1998, s. 129; Tomenčuk B. 2006, s. 38. O Nastazji zob.: Ipat'evskaâ lìtopis'. 1908, szp. 564 


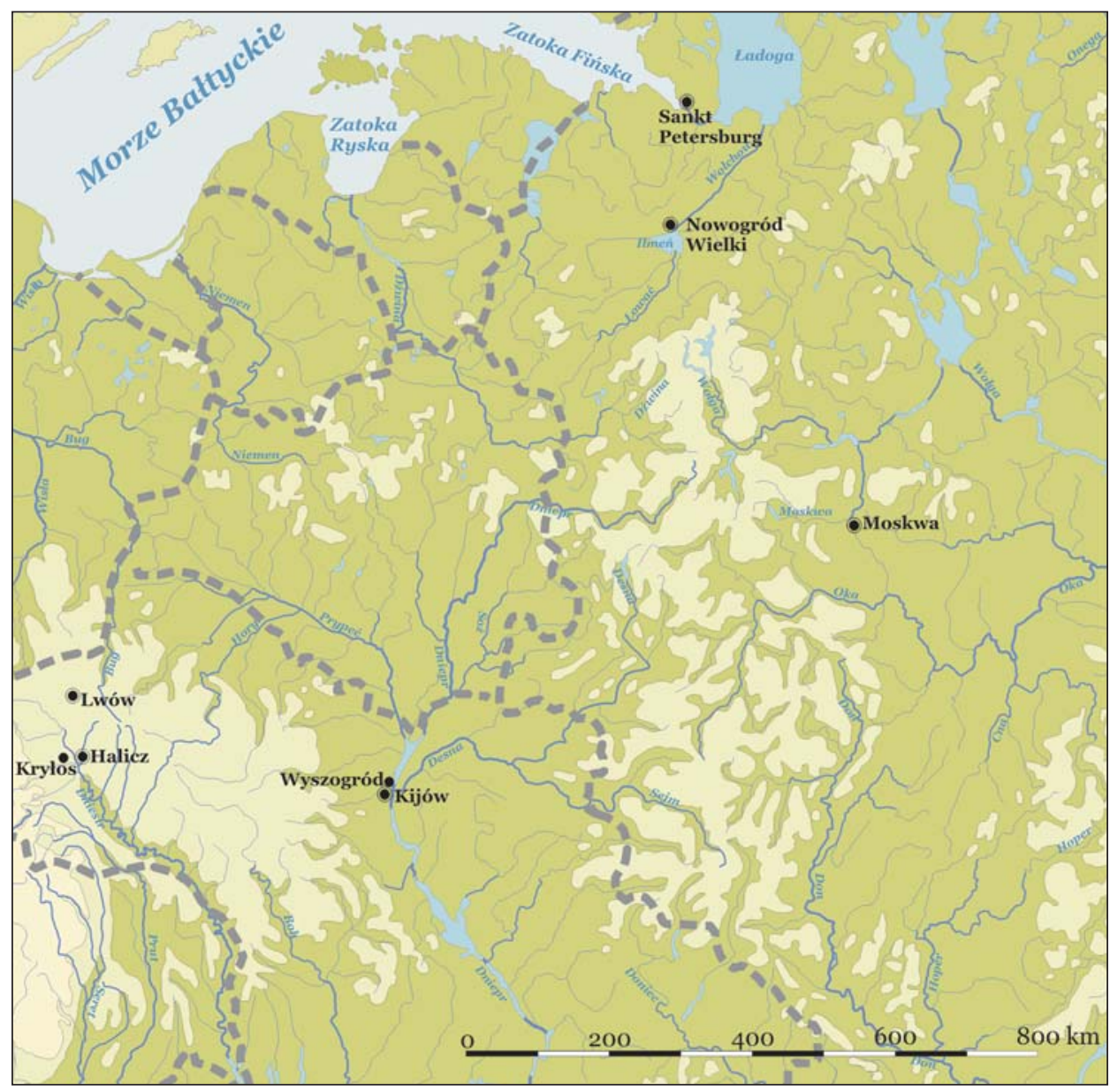

Ryc. 1. Miejscowości wzmiankowane w tekście. Linią przerywaną oznaczono współczesne granice państw. Oprac. K. Skrzyńska

Fig. 1. The places mentioned in the article. The dotted lines mark contemporary state borders. Compiled by K. Skrzyńska

sławica (zwanego w literaturze Udałym), która — według jednej z hipotez — była córką Jarosława $^{20}$. W źródłach pisanych brak danych, które wspierają te spekulacje ${ }^{21}$. W latach dziewięćdziesiątych XX w. przeprowadzono wszakże badania fragmentów tkanki kostnej pochodzących od zmarłych, których szczątki zawierała wspomniana wyżej skrzynka, przy czym te od drugiego osobnika określono jako kobiece ${ }^{22}$. Stwierdzono wówczas obecność antygenu N izoserologicznego systemu ABO, co, jak uznano, potwierdziło identyczność grup krwi oraz bliskie pokrewieństwo zmarłych ${ }^{23}$. W kwestii identyfikacji jednak nie ma pewności ${ }^{24}$. Przeciwnikiem hipotez, że

${ }^{20}$ Gorbenko S. 1996, s. 110-127, 130-131; Vojtovič L. 2006, s. 349, 521; Golovko O. 2017, s. 63-64.

21 Zob.: Dąbrowski D. 2008, s. 441-443; Dombrovskij D. 2015, s. 465-467.

22 Por.: Bandrìvs'kij M. 2015, s. 95-96, tam informacja, że drugie szczątki należały do mężczyzny.

23 Za: Gorbenko S. 1996, s. 93.

${ }^{24}$ Zob.: Kotlâr M. 1996, s. 189; Kotlâr M. 2002, s. 54; Vojtovič L. 2006, s. 346; Golovko O. 2009, s. 38 -39. 
w 1937 r. odkryto w Kryłosie pochówki Jarosława Ośmiomysła oraz kobiety o statusie księżnej, jest lwowski archeolog Mykoła Bandriws'kyj ${ }^{25}$. Problem pozostaje więc otwarty.

Przy szczątkach kobiety pochowanej obok sarkofagu, jak przypuszczano nieco później niż jej „sąsiad”26, znaleziono dwa przedmioty. Na czole „,dosyć dobrze zachowała się opaska z drobno prążkowanego w poprzek brokatu, o długości $310 \mathrm{~mm}$ i szerokości $26 \mathrm{~mm}$, a na niej sześć razy na przemian w przeciwnych kierunkach powtórzony, złotą nitką haftowany motyw dwóch odwróconych jedna od drugiej, grzbietami złączonych spiralek z ozdobnymi «skrzydełkami» po bokach" (ryc. 2) ${ }^{27}$. Włodzimierz Załoziecki (1896-1959) datował ów ornament na początek lub połowę XII w., uznając go za bizantyjski ${ }^{28}$, natomiast zdaniem Władysława Duczki, taki motyw można datować najwcześniej na koniec XI i nie później niż na drugą po-

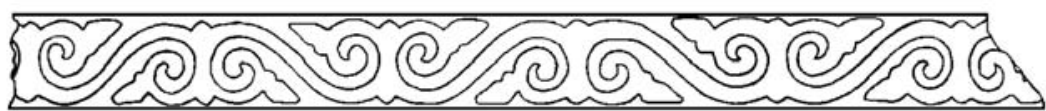

Ryc. 2. Bizantyjski ornament na opasce zdobiącej głowę kobiety pochowanej w grobie w Kryłosie (za: Pasternak Â. 1944, ryc. 45.1; rycina bez skali)

Fig. 2. A Byzantine ornament on the headband from a woman's grave in Krylos (after: Pasternak Â. 1944, fig. 45.1; a drawing with no scale)

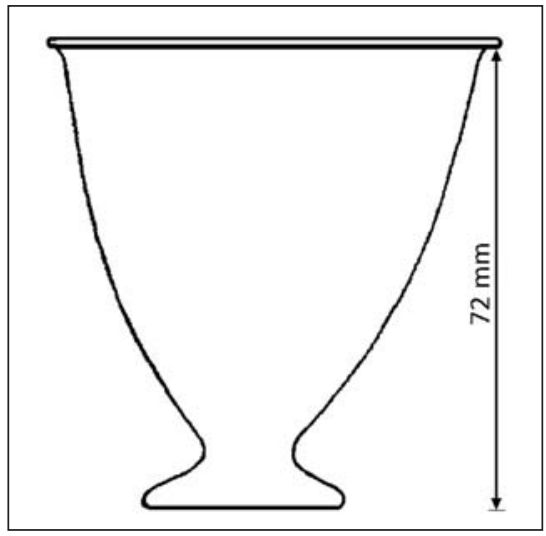

Ryc. 3. Rekonstrukcja naczynia znalezionego przy szczątkach kobiety w soborze katedralnym w Haliczu (za: Pasternak Â. 1944, ryc. 48)

Fig. 3. A reconstruction of the glass vessel found in a woman's grave in the Orthodox cathedral in Halych (after: Pasternak Â. 1944, fig. 48) łowę XII w., i faktycznie może pochodzić z Bizancjum ${ }^{29}$.

Drugi przedmiot to stojące w grobie za głową zmarłej naczynie szklane formy tulipanowatej i zielonkawo-żółtego koloru, o bardzo cienkich ściankach, określone w publikacji jako ,szklaneczka”30. Było potłuczone, ale Pasternak przedstawił je na rysunku ${ }^{31}$ jako mające $72 \mathrm{~mm}$ wysokości, wylew o średnicy $75 \mathrm{~mm}$ oraz dno o średnicy $32 \mathrm{~mm}$ (ryc. 3). Ukraiński archeolog uznał naczynie za ,na pewno" pochodzenia bizantyjskiego i datował na wiek XII. Podstawą do tego było znalezisko dolnej części „dokładnie takiej samej szklaneczki” odkrytej wraz z ułamkami glinianego naczynia, datowanego również na wiek XII, na terenie uroczyska Zoło-

25 Zob.: Bandrìvs'kij M. 2005, s. 131 n.; Bandrìvs'kij M. 2015, s. 95-97.

26 Pasternak Â. 1944, s. 140.

27 [...] досить добре збереглося чільие з дрібно пружкованої упоперек парчі, 310 мм. завдовжки i 26 мм. завширики, а на ньому шість разів напереміну в протилежних позиціях повторений, золотою ниткою гаптований мотив двох відвернених одна від одної, спинками стулених спіральок з оздобними «крильиями» по боках, Pasternak Â. 1944, s. 140; por.: Pasternak Â. 1938, s. 64.

28 Za: Pasternak Â. 1938, s. 64; Pasternak Â. 1944, s. 125.

29 Konsultacja ustna.

30 скляночка, Pasternak Â. 1944, s. 140.

31 Вона вся побита, так щчо можна було відтворити ї̈ лише на рисунку, Pasternak Â. 1944, s. 140. 
tyj Tik w Kryłosie ${ }^{32}$, gdzie część badaczy lokalizuje dwór książęcy z XI-XII w. ${ }^{33}$ W pierwszej publikacji dotyczącej wykopalisk prowadzonych latem 1938 r. na wspomnianym uroczysku Pasternak jednak stwierdził, że znalazł tam fragmenty „szklanki” „podobnej” do tej, odkrytej przy pochówku kobiecym w soborze katedralnym oraz bardzo dużą liczbę fragmentów naczyń glinianych, wśród których większość datowano na XII-XIII stulecie ${ }^{34}$. Natomiast w innym miejscu książki o „Starym Haliczu” Autor napisał, że znaleziono „fragmenty szklanki tego samego typu”, dodając, iż na liczne fragmenty takich „szklanek” natrafiono też w Kijowie, w obrębie posesji dr. M.M. Petrows'kiego (współcześnie teren Narodowego Muzeum Historii Ukrainy) ${ }^{35}$. Może tu chodzić o wykopaliska w latach 1936-1937 lub/i 1938-1939. Pierwszymi, prowadzonymi przez Instytut Historii Kultury Materialnej Akademii Nauk URSR, kierował zamordowany w trakcie tzw. Wielkiej Czystki (zob. też niżej) Todosij Mowczaniws'kyj (1899-1938) ${ }^{36}$, o czym jednak brak wzmianek w publikacjach wydanych po $1938 \mathrm{r}^{37}$ Prawdopodobnie w trakcie wspomnianych prac znaleziono dna szklanych naczyń, których fotografię opublikował Michaił Konstantinowicz Kargier (1903-1976) ${ }^{38}$, kierujący drugim etapem prac zorganizowanym przez Instytut Archeologii AN URSR wespół z Instytutem Historii Kultury Materialnej AN SSSR ${ }^{39}$.

W monografii z 1944 r. Pasternak nie wspomniał o dalszych losach ,szklaneczki”, zwrócił natomiast uwagę, że podczas wykopalisk prowadzonych w Kijowie w 1909 r. pod kierownictwem Dmitrija Wasiljewicza Milejewa (1878-1914), w miejscu, gdzie znajdowała się Cerkiew Dziesięcinna $^{40}$, w grobach z „książęcych czasów” znaleziono resztki naczyń z cienkiego, kruchego szkła i uznano, że w nich dawano zmarłym do grobu poświęcony olej. Badacz stwierdził następnie, że „szklaneczka” odkryta w Kryłosie miała „z pewnością” to samo przeznaczenie ${ }^{41}$. W publikacji informującej o wykopaliskach D.W. Milejewa nie podano szczegółowych informacji dotyczących kształtów odkrytych wówczas naczyń. Dowiadujemy się, że w kilku grobach, przypuszczalnie datowanych na czasy metropolity kijowskiego Piotra Mohyły (zm. w 1646/ 1647 r.), znaleziono „małe szklane naczynie na kształt szklaneczki/kieliszka”42, zaś w datowanych na X w. ,pozostałości szklanych naczyń”³. W liście z 22 maja 1909 r. Milejew napisał do swojego nauczyciela, Borisa Władimirowicza Farmakowskiego (1870-1928), że w grobach „[...] trafiają się nieduże szklane naczynia z bardzo cienkiego i kruchego szkła, ale wszystkie rozgniecione" ${ }^{44}$. Dokumentacja polowa z wykopalisk Milejewa była uważana za zaginioną.

32 урочище Золотий Тік, Pasternak Â. 1944, s. 140.

33 Zob.: Lâska V. 2008, s. 470-472; Tomenčuk B. 2013.

34 Pasternak Â. 1939, s. 13.

35 в садибі Петровського, Pasternak Â. 1944, s. 183, przyp. 365.

36 Zob. m.in.: Belâěva S., Kalûk O. 1989; Šovkoplâs G. 2000; Pavlova V. 2003.

37 Zob. np.: Karger M.K. 1940; Karger M.K. 1952; Karger M.K. 1958, s. 59 n.; Korzuhina G.G. 1956; por. też Kozûba V. 2015.

${ }^{38}$ Zob. przyp. 60 oraz ryc. 5. Brak jednak informacji na ten temat w sprawozdaniu opublikowanym latem 1936 r. (zob.: Âčmen'ov N., Molčanovs'kij F. 1936).

39 Zob.: Karger M.K. 1958, s. 57-59; Kozûba V. 2015; Kozûba V. 2018. O odkrywaniu małych, cienkościennych, kruchych naczyń szklanych, rozpadających się przy najmniejszym dotknięciu, wzmiankuje też Wikentij Chwojka (1850-1914), który kopał na terenie działki Petrows'kiego w 1907 i 1908 r., Hvojka V.V. 1913, s. 72; zob. też Karger M.K. 1952; Karger M.K. 1958, s. 52-53; Korzuhina G.F. 1956; Kozûba V. 2006; Kozûba V. 2010.

${ }^{40}$ Zob. o tych wykopaliskach: Karger M.K. 1958, s. 53-57; Ëlšin D.D. 2009; Ëlšin D.D., Melûh E.A., Hodakovskij E.V. 2015, s. 141-157.

41 Pasternak Â. 1944, s. 140.

42 маленькій стекланный сосудъ на подобіе стаканчика, Raskopki. 1909, s. 124.

43 остатки стеклянныхъ сосудовъ, Raskopki. 1909, s. 125.

44 [...] встречаются небольшие стеклянные сосуды из очень тонкого и хрупкого стекла и все раздавленьл, za Ëlšin D.D., Melûh E.A., Hodakovskij E.V. 2015, s. 358; także Pekars'ka L. 2016, s. 169. 
Jej część udało się odnaleźć w 1995 r. w Kijowie oraz w 2005 r. w Sankt Petersburgu. W artykułach jej dotyczących nie ma informacji o tych szklanych znaleziskach ${ }^{45}$.

Problem określenia tego, do czego mógł służyć kryłoski przedmiot, zostanie rozpatrzony $\mathrm{w}$ odrębnym opracowaniu. Związany jest bowiem z zagadnieniem umieszczania w grobach naczyń, w których pierwotnie znajdował się, zdaniem badaczy, poświęcony olej używany w trakcie obrzędów pogrzebowych.

\section{Historia rekonstrukcji}

Naczynie z Kryłosu wspominane jest w literaturze opublikowanej po roku 1945. ,„[...] cały pucharek [...] znaleziony w grobowcu Jarosława Włodzimierzowica Ośmiomysła [...] w Haliczu"46 przywołał jako przykład Boris Aleksandrowicz Rybakow (1908-2001). Uczynił to, wzmiankując o szklanych pucharkach ${ }^{47} \mathrm{z}$ cienkimi i kruchymi ściankami, którym przypisano „dosyć masywne i dobrze zachowane okrągłe dna, połączone krótkim przewężeniem ze stożkowatym korpusem" ${ }^{48}$, licznie znajdowane zwłaszcza w ,południowych miastach”, w warstwach datowanych na XI-XIII w. ${ }^{49}$ Również M.K. Kargier odnotował częste znaleziska den, nie wykraczając jednak poza informacje przekazane przez Rybakowa, oraz fakt, że pozostałe części naczyń rozpadają się na „drobne kruche kawałki”, podkreślając, iż całe zachowało się „tylko jeden raz w całości” w Haliczu. Scharakteryzował je następująco: „zrobione zostało w drodze wydmuchania z całego półproduktu. Górna jego część oddzielona była od okrągłej nóżki krótkim przewężeniem, dno wtłoczono do środka". Nie podał, na jakiej podstawie powstał ten opis ${ }^{50}$. Wołodymyr Fedorowycz Rożankiws'kyj (1906-1973) opisał zaś stan zachowania omawianego naczynia w chwili odkrycia, stwierdzając, że zanim naczynie się rozpadło, zmierzono je i odrysowano. Zaznaczył, że w ten sposób zyskano materiał pozwalający odtworzyć formy innych „kieliszków”, które, jak można sądzić na podstawie den, były prawie tego samego rozmiaru. Uważał, że mieściło się w nich ok. 200 g płynu ${ }^{51}$. Ukraiński badacz nie zamieścił jednak odpowiednich odnośników bibliograficznych. Bejbut Aleksandrowicz Szełkownikow (1897-1974) natomiast zaznaczył, że pucharek „rozsypał się po znalezieniu" 52 .

B.A. Rybakow nadmienił, że ok. setki den od szklanych pucharków o cienkich i kruchych ściankach, takich, jak odkryty w Kryłosie, znaleziono w 1935 r. „w trakcie jego wykopalisk” w Wyszogrodzie (rejon wyszogrodzki, obwód kijowski) ${ }^{53}$. Wzmiankę przywoływano później ${ }^{54}$, ale próżno szukać w literaturze opracowania tych zabytków. Pracami ekspedycji Instytutu Historii Kultury Materialnej Wszechukraińskiej Akademii Nauk ${ }^{55}$ działającej w Wyszogrodzie kiero-

45 Zob.: Gribanova N. 1996; Kozûba V. 2005; Kozûba V. 2014; Ëlšin D.D. 2007; Peskova A.A. 2012; Pekars'ka L. 2016.

46 иелый бокал был найден в гробнице Ярослава Владимировича Осмомысла (1187) в Галиче, Rybakov B.A. 1948 , s. 398.

$47 \mathrm{~W}$ literaturze przedmiotu stosowano różne nazwy w odniesieniu do typu naczynia reprezentowanego przez znalezisko z Kryłosu. Właściwym terminem jest jednak „pucharek” lub „kieliszek”.

48 круглое дно, довольно массивное и хорошо сохранившееся, соединенное коротким перехватом с коническим корпусом, Rybakov B.A. 1948, s. 398.

49 в Киеве и других южных городах, Rybakov B.A. 1948, s. 398.

50 Бокал этот [...] выполнен путем выдувания из целой заготовки. Верхняя часть его отделена от круглой ножки коротким перехватом, дно вдавлено внутрь, Karger M.K. 1958, s. 409.

51 Rožankìvs'kij V.F. 1959, s. 25.

52 Šlkovnikov B.A. 1959, s. 116.

53 при моих раскопках, Rybakov B.A. 1948, s. 398.

54 Bezborodov M.A. 1956, s. 229; Karger M.K. 1958, s. 409; Rožankìvs'kij V.F. 1959, s. 25; Šelkovnikov B.A. 1959, s. 115; Ŝapova Û.L. 1972, s. 34, 36.

55 Instytucja ta od 1936 r. pod nazwą Akademia Nauk USRR, od 1937 r. — Akademia Nauk URSR. 
wali ukraińscy archeolodzy — Fedir Kozubows'kyj (1895-1938[?]), w latach 1934-1935 dyrektor IHKM WAN, oraz wspomniany już T. Mowczaniws'kyj, w okresie od 1936 do 1937. Obaj jednak stali się ofiarami tzw. Wielkiej Czystki ${ }^{56}$. B.A. Rybakow był członkiem ekspedycji z ramienia moskiewskiego Państwowego Muzeum Historycznego. Przemilczano też udział samego Pasternaka, nie wspomniano bowiem jego nazwiska w publikacji przedstawiającej wyniki prac halickiej ekspedycji z 1951 r., mimo że przywoływano jego ustalenia i pozyskane materiały ${ }^{57}$.

W artykule z 1950 r., będącym omówieniem nieopracowanych wówczas odkryć w Wyszogrodzie w latach 1934-1937, autorstwa Wasyla Jiosypowycza Dowżenka (1909-1976), który prowadził tam badania w 1947 r., brak informacji o licznych znaleziskach den szklanych wyrobów (i o kierownikach wyszogrodzkiej ekspedycji). Napisano o fragmentach szklanych „flakonów”/,butelek",58, zaś na jednej z rycin przedstawiono „dolną część” takiego naczynia (ryc. 4). Nie podano, na jakiej podstawie powstał rysunek, podkreślono natomiast na wstępie, że całkiem utracone zostały metryki, a najcenniejsza część materiałów i dokumentacji z przedwojennych badań zaginęła w czasie niemieckiej okupacji Kijowa ${ }^{59}$. Nie wiemy, kto, gdzie

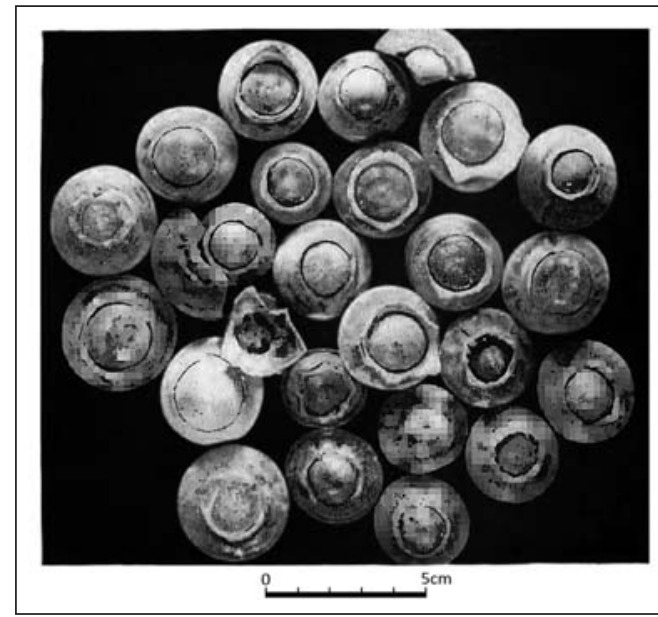

Ryc. 5. Dna pucharków z wykopalisk z lat $1936-1937$

(za: Karger M.K. 1958, tabl. LXIX, 2)

Fig. 5. Goblet bottoms excavated in 1936-1937

(after: Karger M.K. 1958, table LXIX:2)

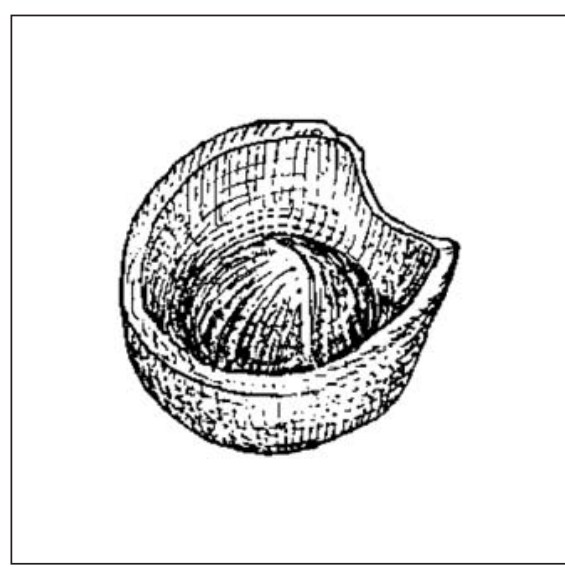

Ryc. 4. Dolna część szklanego naczynia (flakonu/butelki) z Wyszogrodu na Ukrainie (za: Dovženok V.Ï. 1950, tabl. VII, rys. 18; rycina bez skali)

Fig. 4. The bottom part of a glass vessel (flacon/bottle) from Vyshhorod in Ukraine, no dating (after: Dovženok V.Ï. 1950, table

VII, fig. 18; a drawing with no scale)

i kiedy zrobił zdjęcie zamieszczone w monografii M.K. Kargiera z 1958 r. o Kijowie średniowiecznym (ryc. 5), przedstawiające dna, dla których jako przykład wskazano znaleziska Rybakowa oraz dno kryłoskiego pucharka. Autor podał, że pochodzą one z wykopalisk przeprowadzonych w latach 1936-1937, jednak pominął informację, gdzie zostały one zrealizowane ${ }^{60}$. Można przypuszczać, że dna prezentowane na fotografii w książce Kargiera pozyskano we wspomnianym okresie w Kijowie, na terenie dzisiejszego Narodowego Muzeum Historii Ukrainy (por. wyżej). Według

\footnotetext{
56 Zob.: Kolesnìkova V., Pavlenko S. 2017; por. też literatura zamieszczona w przyp. 36.

57 Gončarov V.K. 1955; Gončarov V.K. 1956; zob. też Pasternak Â. 1958, s. 12.

58 скляні флакони, Dovženok V.Ï. 1950, s. 71.

59 Dovženok V.Ï. 1950, s. 68.

${ }^{60}$ Karger M.K. 1958, s. 409, 571.
} 
Juliji Leonidownej Szczapowej (1930-2019) znaleziono je w Kijowie podczas prac prowadzonych w różnych latach ${ }^{61}$.

Na początku lat pięćdziesiątych XX w. przeprowadzono badania składu ,ułamka szklanego pucharka", z wykopalisk B.A. Rybakowa w Wyszogrodzie, przekazanego przez Marię Wasiljewnę Fechner (1909-1969) z Państwowego Muzeum Historycznego w Moskwie. Nie wzmiankowano, w którym roku został on znaleziony, nie zamieszczono też innych danych $^{62}$. Publikujący wyniki analizy Michaił Aleksiejewicz Biezborodow (1898-1983) przypuszczał, że przebadany fragment pochodził z naczynia o takim kształcie, jaki miało naczynie przedstawione w książce Josifa Adamowicza Chojnowskiego (1833-1919) dotyczącej wykopalisk w Kijowie w 1892 r. ${ }^{63}$ Nie wskazał, o którą rycinę z książki Chojnowskiego chodzi $^{64}$. Zamieszczony przez Biezborodowa rysunek (ryc. 6A) obrazuje jednak naczynie szklane znalezione w Kijowie na Górze Zamkowej lub na ulicy Kyryliws'kiej, w nieokreślonych bliżej okolicznościach ${ }^{65}$. Fotografię zabytku zawiera piąty tom publikacji poświęconej przedmiotom z kijowskiej kolekcji Chanienków (ryc. 6B). Reprezentuje on inny typ naczyń niż pucharek z Kryłosu ${ }^{66}$.
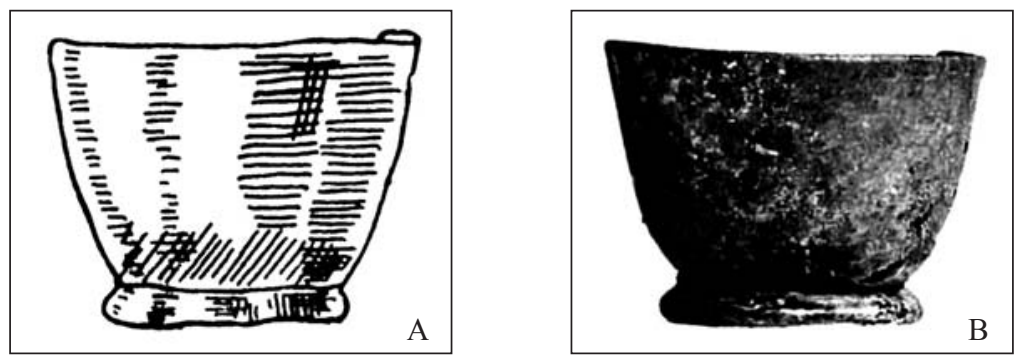

Ryc. 6. Naczynia szklane (ryciny bez skali): A — znalezione w Kijowie [?] (za: Bezborodov M.A. 1956, rys. 32b); B — z kijowskiej kolekcji Chanienków (za: Sobranie. 1902, tabl. XXXV, nr 1259)

Fig. 6. Glass vessels from Kiev, no dating (drawings with no scale): A — found in Kiev [?] (after: Bezborodov M.A. 1956, fig. 32b); B - in the Khanenko Collection (after: Sobranie. 1902, table XXXV, no 1259)

B.A. Szełkownikow zwrócił uwagę, że w Muzeum Historycznym we Lwowie znajdował się fragment pucharka $\mathrm{z}$ białego szkła o słabym zielonkawym odcieniu, odkryty razem z ceramiką na terenie uroczyska Zołotyj Tik w Kryłosie, datowany na XI-XII w. Jego stopkę uznał

${ }_{61}$ Ŝapova Û.L. 1972, s. 32. Również w odkrytych na kijowskim Padole w 1950 r. pozostałościach po warsztacie szklarskim, datowanym na koniec XI-początek XII w., stwierdzono ułamki m.in. cienkościennych naczyń, w tym ścianki niewielkich pucharków oraz okrągłe dna (Bogusevič V.A. 1954, s. 14-15). Niewielką liczbę den znaleziono w warsztacie szklarskim odkrytym w 1951 r. w Kijowie, na terenie Ławry Pieczarskiej, działającym pod koniec XI w. (Ŝapova Û.L. 1972, s. 33; por. Bogusevič V.A. 1954, s. 20).

62 Zob.: Bezborodov M.A. 1956, s. 235.

${ }^{63}$ Hojnovskij I.A. 1893.

${ }^{64}$ Bezborodov M.A. 1956, s. 235 i rys. 32b.

65 Sobranìe. 1902, s. 18, 59 .

${ }^{66}$ M.A. Biezborodow, a także B.A. Szełkownikow uznali, że naczynie, z którego pochodził przebadany ułamek, zostało wykonane na Rusi (Bezborodov M.A. 1956, s. 235; Šelkovnikov B.A. 1959, s. 116-117, przyp. 16). Warto jednak zwrócić uwagę, że to wapniowo-potasowe popiołowe szkło krzemowe, niezawierające tlenku ołowiu (zob. Bezborodov M.A. 1956, s. 232, tabl. 30, nr 22), a taki skład chemiczny wskazuje raczej na wyroby szklane z Europy Zachodniej; zob. szerzej: Ŝapova Û.L. 1963, s. 131-135; Ŝpova Û.L. 1972, s. 29-30; Ŝpova Û.L. 2008, s. 78 n.; Dekówna M. 1980, s. 285; Galibin V.A. 2001, s. 82 n.; Stolârova E.K. 2015, s. 339-340. 

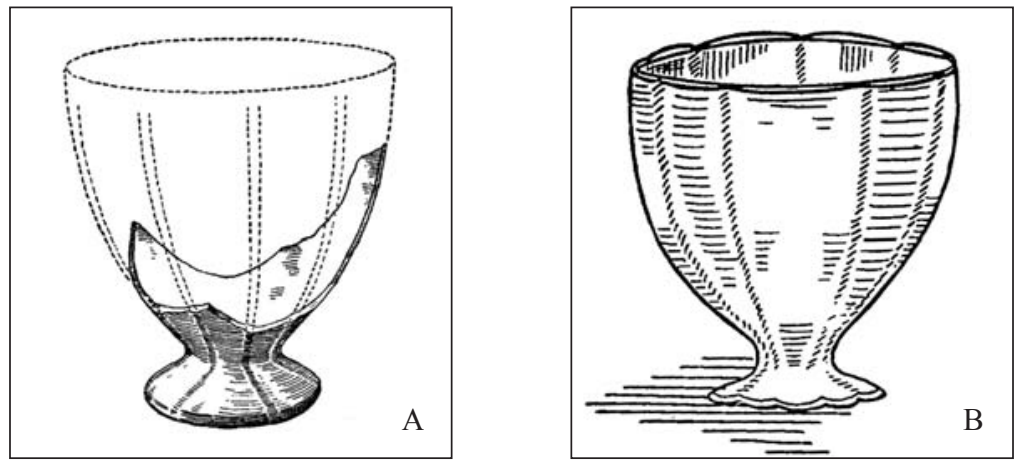

Ryc. 7. Rekonstrukcje szklanych pucharków z Muzeum Historycznego we Lwowie, z fragmentów odkrytych w Kryłosie (ryciny bez skali): A — pucharek z XI-XII w. (za: Šelkovnikov B.A. 1959, ryc. 1 s. 116); B - pucharek z XII w. (za: Rožankivsk'ij V.F. 1959, ryc. 4e)

Fig. 7. Reconstructions of glass goblets from the Museum in Lviv, based on fragments found in Krylos (drawings with no scale): A - a goblet from the 11th-12th c. (after: Šelkovnikov B.A.

1959, fig. 1 p. 116); B - a goblet from the 12th c. (after: Rožankivsk'ij V.F. 1959, fig. 4e)

za należącą do tego samego typu, co stopki szklanych wyrobów znalezione w Wyszogrodzie ${ }^{67}$. Przyjął, że na podstawie lwowskiego fragmentu można odtworzyć formę takich naczyń (zob. ryc. 7A) i opisał je następująco: „Szeroka niewysoka czasza, typowa stopka, otrzymana w procesie wydmuchania ze wspólnego także dla czaszy szklanego półproduktu, z krótkim, niezbyt wąskim przewężeniem i głęboko wtłoczonym dnem. Denka wtłoczone do zetknięcia się z wewnętrznymi ściankami pucharka, tak, aby oddzielić od czaszy wolną przestrzeń stopki”"68. Podkreślił, że ścianki lwowskiego egzemplarza są ozdobione dziewięcioma pionowymi żebrami, wypukłymi zarówno wewnątrz, jak i na zewnątrz, widocznymi również na stopce. Wnioskował, że najpierw półprodukt został ozdobiony żebrami, a następnie uformowano stopkę. Szełkownikow dodał, iż na taki pucharek natrafiono w Kryłosie przy pochówku kobiecym sąsiadującym z grobem Jarosława Ośmiomysła. Jego krawędź była tylko nieco grubsza, a dna różniły się średnicą jedynie o $0,3 \mathrm{~cm}$. Nadmienił też, że w Muzeum Historycznym we Lwowie przechowywane były dwa egzemplarze znalezionych w Kryłosie w 1940 r. identycznych den, ale o nieco większych rozmiarach (w średnicy 4-5 cm) i grubszych ściankach $(2-2,5 \mathrm{~mm})$; dla pucharka odkrytego w kobiecym grobie w soborze katedralnym przyjął bowiem grubość ścianki ok. $1 \mathrm{~mm}$. Ponieważ na tych dnach nie stwierdził żeber, uznał, że ozdabiano nimi jedynie cienkościenne pucharki mniejszych rozmiarów ${ }^{69}$. Również W.F. Rożankiws'kyj wspomniał o „kieliszku” z Muzeum we Lwowie, z dziewięcioma równomiernie rozmieszczonymi żebrami, znalezionym na uroczysku Zołotyj Tik razem z ceramiką dwunastowieczną. Zrekonstruował go (ryc. 7B) i stwierdził, że kształt i sposób wykonania stopki są identyczne jak naczynia z grobu kobiecego z soboru w Kryłosie ${ }^{70}$. Nie wyjaśnił jednak podstaw takiego wnioskowania.

W książce z 1972 r., poświęconej szkłom Rusi Kijowskiej, Ju.L. Szczapowa zamieściła rysunki: dna o średnicy $3 \mathrm{~cm}$, znajdującego się w Kijowskim Muzeum Historycznym (dziś Narodowe Muzeum Historii Ukrainy w Kijowie), nie podając, gdzie i kiedy zostało ono znale-

${ }^{67}$ с ножкой того же вида, как и найденные Б. А. Рыбаковыл, Šelkovnikov B.A. 1959, s. 115.

68 Они имеют широкое невысокое пойло, типичную ножку, полученную в процессе выдувания из одной с пойлом стеклянной заготовки, с коротким, не слишком узким перехватом и глубоко вдавленным дном. Донышки вдавливались до соприкосновения с внешними стенками бокала; последнее было необходимо для того, чтобы отделить свободное пространство кольцевой ножки от пойла, Šelkovnikov B.A. 1959, s. 116.

69 Šelkovnikov B.A. 1959, s. 116. 


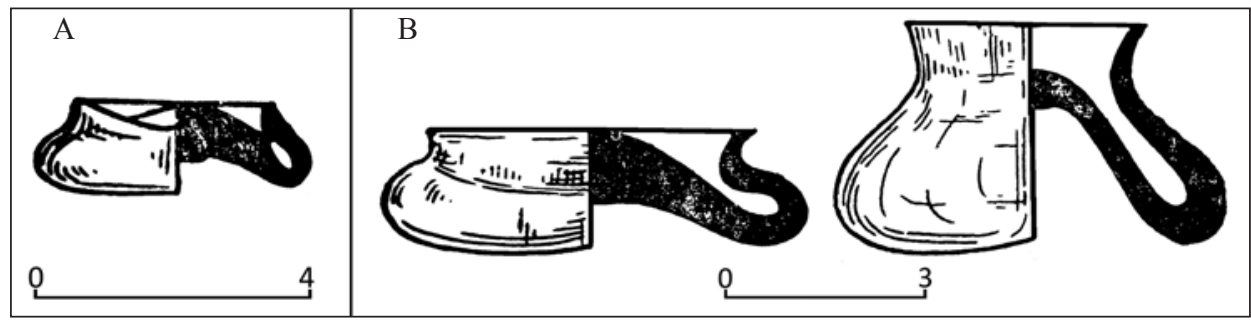

Ryc. 8. Dna szklanych naczyń ze stopką, niedatowane: A — ze zbiorów Kijowskiego Muzeum

Historycznego, pochodzące z nieznanego stanowiska (za: Ŝapova Û.L. 1972, rys. 2:1);

B - z kolekcji Instytutu Archeologii AN USSR w Kijowie, znalezione w Wyszogrodzie na Ukrainie (za: Ŝapova Û.L. 1972, rys. 3: 1, 2)

Fig. 8. The bottoms of footed glass vessels, no dating: A - in the Museum in Kiev, from an unspecified site (after: Ŝapova Û.L. 1972, fig. 2:1); B - in the collection of the Institute of Archaeology of the Academy of Sciences of the USSR in Kiev, found in Vyshhorod in Ukraine (after: Ŝapova Û.L. 1972, fig. 3: 1, 2)

zione (ryc. 8A), oraz fragmentów dwóch naczyń o masywnych dnach „z podstawą” (stopką) znalezionych w Wyszogrodzie (ryc. 8B), pochodzących ze zbiorów ówczesnego Instytutu Archeologii AN USSR w Kijowie. W tej ostatniej placówce zgromadzonych było wówczas 13 egzemplarzy takich den. Nie wyjaśniła, kiedy je odkryto, ale odnotowała, że część materiałów z wykopalisk przeprowadzonych w Wyszogrodzie w 1937 r. pod kierownictwem B.A. Rybakowa przechowywano w Państwowym Muzeum Historycznym w Moskwie oraz w Instytucie Archeologii AN USSR w Kijowie, inne zaginęły podczas II wojny światowej, natomiast pewna część znajduje się w ukraińskich i rosyjskich muzeach, przy czym wiele fragmentów nie ma już metryk ${ }^{71}$.

Szczapowa, ustalając kształty den staroruskich naczyń, jako typ czwarty wydzieliła dna „,Z wysokim wklęsłym stożkiem” (tj. mocno wysklepione do wewnątrz) oraz z pustą wewnątrz „podstawką” (stopką). Podkreśliła, odsyłając do wzmianki Rybakowa o wyszogrodzkich znaleziskach oraz do fotografii w książce Kargiera, że dna tego typu „są najbardziej rozpowszechnionymi znaleziskami wśród fragmentów naczyń szklanych"72. Zwróciła też uwagę, że w Haliczu, koło sarkofagu Jarosława Ośmiomysła, natrafiono na ,jedyne całe ruskie średniowieczne naczynie szklane, koloru jasno-oliwkowego, mające dno typu 4"73. Pasternak natomiast barwę szkła określił jako zielonkawo-żółtą ${ }^{74}$. Autorka stwierdziła, że takie naczynie miało „ciężkie, dość stabilne i bezsprzecznie trwałe denko, [oraz - K.K.] szeroką, ale lekką i zarazem pojemną czaszę, [które — K.K.] ostro kontrastując, wzajemnie siebie równoważyły"75. Podkreśliła, że daje się zauważyć różne połączenia rozmiarów czasz i den, na małych dnach mogła bowiem opierać się zarówno duża, jak i mała czasza ${ }^{76}$. Zaproponowała również rekonstrukcję form

70 Rožankivs'kij V.F. 1959, s. 27.

71 Sapova Û.L. 1972, s. 34, przyp. 25.

72 являются самой распространенной находкой среди фрагментов стеклянной посуды, Ŝapova Û.L. 1963, s. 123.

73 единственный цеелый русский сосуд светло-оливкового иявета, имеющий днище 4 типа, Ŝpova Û.L. 1963, s. 123.

74 Pasternak Â. 1944, s. 140.

75 Тялелое, достаточно устойчивое и, бесспорно, прочное доние, иикорий, но легкий и вместе с тем вместительный основной объем, уравновешивая друг друга, резко контрастировали, Sapova Û.L. 1972, s. 38.

76 Sapova Û.L. 1972, s. 58-59. 


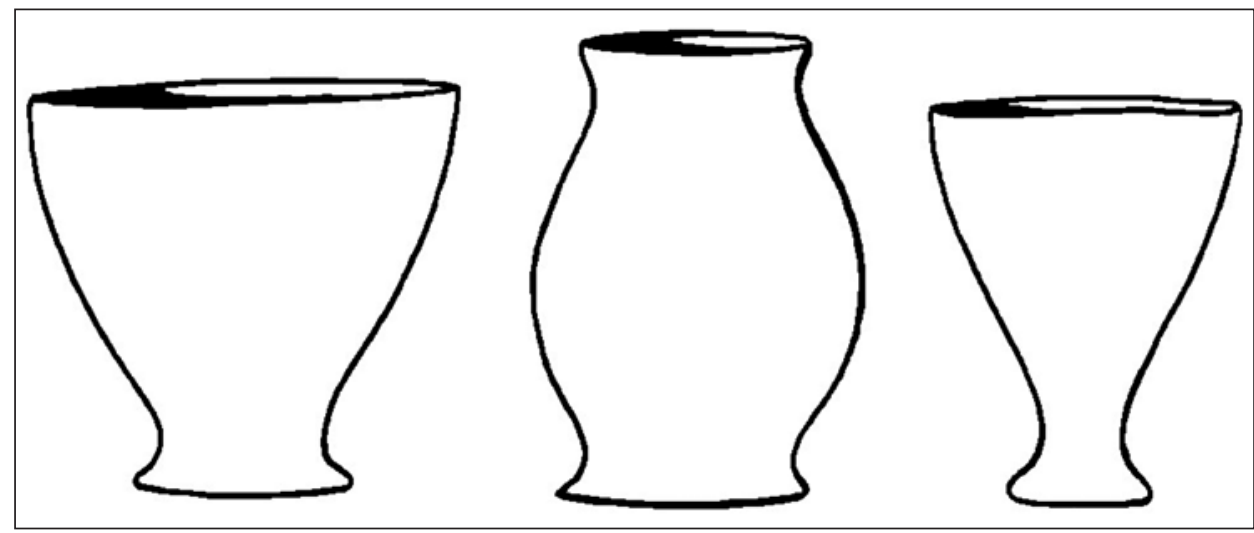

Ryc. 9. Rekonstrukcje staroruskich naczyń z wysokim wklęsłym dnem i pustą wewnątrz stopką (za: Ŝapova Û.L. 1963, ryc. 8: 8, 9, 13; ryciny bez skali)

Fig. 9. Reconstructions of Old-Ruthenian vessels with high concave bottoms and hollow feet (after: Ŝapova Û.L. 1963, fig. 8: 8, 9, 13; drawings with no scale)

naczyń, które mogły mieć dna tego typu (ryc. 9; ryc. 10A), w tym egzemplarza z Nowogrodu, posiadającego dno ,z podstawką” (ryc. 10B).

Zmarła niedawno badaczka starożytnego i średniowiecznego szkła określiła pojawienie się naczyń ,z podstawką” na lata trzydzieste XII w., zaś zaprzestanie ich użycia na lata sześćdziesiąte tego stulecia ${ }^{77}$. Natomiast w publikacji z 1997 r. naczynie z Kryłosu Szczapowa opisała jako mające formę obciętego stożka i zaznaczyła, że nie zachowało się ${ }^{78}$. Zaliczyła je do typu wyrobów, które pojawiły się na Rusi w drugiej połowie XII w., o charakterystycznym dnie z wysokim wklęsłym „stożkiem” oraz pustą wewnątrz „,podstawką”. Nie wyjaśniła jednak, najpewniej przez wzgląd na syntetyczny charakter pracy, na jakich podstawach ustalono to datowanie ${ }^{79}$.

\section{Dalsze losy kryłoskiego naczynia}

Dotychczasowe ustalenia prowadzą do wniosku, że pucharek znaleziony w 1937 r. w kobiecym grobie w soborze katedralnym w Kryłosie nie przetrwał do naszych czasów. Źródłem wiedzy o jego wyglądzie jest rysunek zamieszczony w książce Jarosława Pasternaka, opublikowanej w 1944 r. W artykule z 2014 r., będącym omówieniem wyników poszukiwań w muzealnych kolekcjach materiałów m.in. z tamtych wykopalisk archeologicznych, natrafiamy na zaskakującą informację, że szklane naczynie z kryłoskiej świątyni znajduje się w Muzeum Narodowym we Lwowie ${ }^{80}$.

\section{Wnioski}

Dwunastowieczna chronologia pucharka znalezionego w grobie kobiecym w soborze katedralnym w Kryłosie wydaje się nie budzić wątpliwości. W rozważaniach dotyczących kontekstu jego odkrycia jest wciąż wiele domysłów oraz hipotez i potrzebne są krytyczne studia

77 Ŝapova Û.L. 1972, s. 47, 58.

78 сосуд [...] не дошел до нас, Ŝapova Û.L. 1997, s. 31.

79 Ŝapova Û.L. 1997, s. 32.

${ }_{80}$ Фонди Національного музею [у Львові - К.К.] містять предмети, переважно, мистецької вартості з розкопок Я. Пастернака: бронзові та срібні культові речі, зокрема скляний флакон з жіночого поховання в Успенському соборі тощю, Ters'kij S., Omel'čuk B. 2014, s. 92; zob. też: Omel'čuk B. 2016, s. 39. 

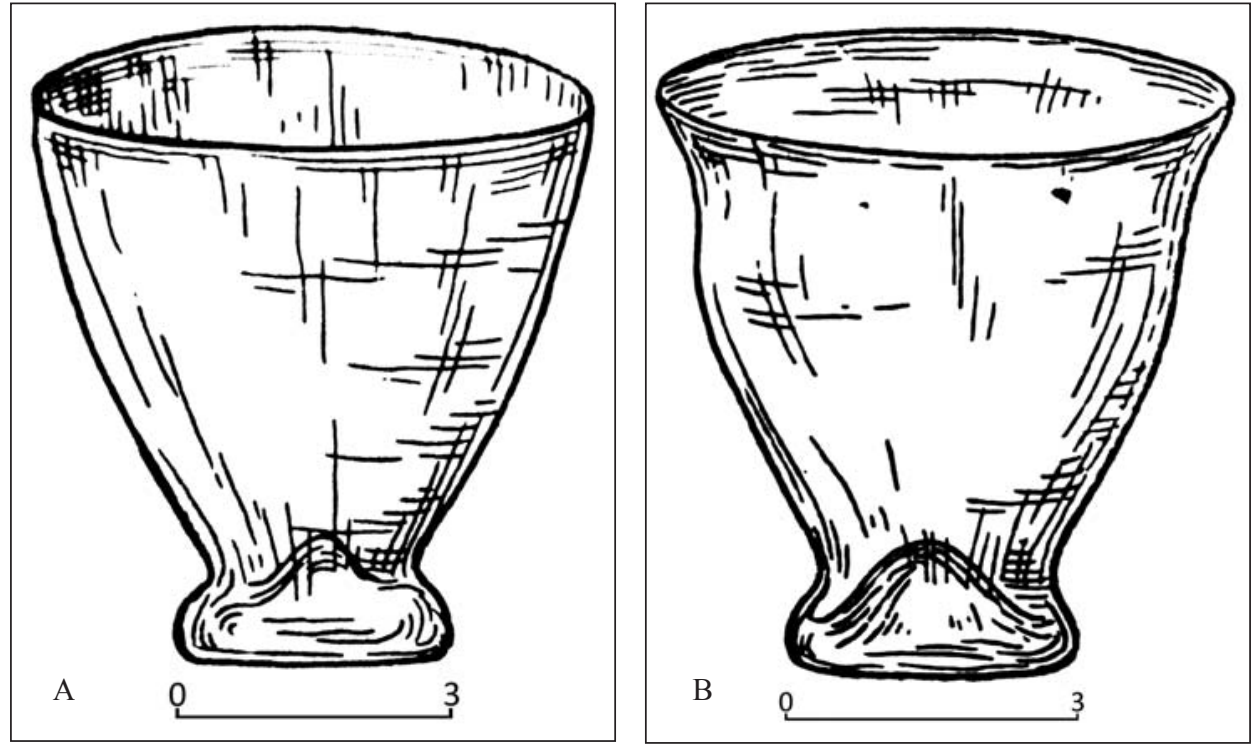

Ryc. 10. Rekonstrukcje naczyń szklanych: A — staroruskiego, z wysokim, wklęsłym dnem i pustą wewnątrz stopką (za: Ŝapova Û.L. 1972: rys. 11:16); B — z Nowogrodu, o dnie ze stopką (za: Ŝapova Û.L. 1972: rys. 7:5)

Fig. 10. Reconstructions of glass vessels: A - an Old-Ruthenian vessel with a high concave bottom and a hollow foot (after: Ŝapova Û.L. 1972: fig. 11:16);

B - from Novgorod, with a footed bottom (after: Sapova Û.L. 1972: fig. 7:5)

weryfikujące stan badań nad poszczególnymi zagadnieniami. Jest to jednak trudne z uwagi na brak dokumentacji z prac w Kryłosie kierowanych przez Jarosława Pasternaka. Badacze na ogół posługują się danymi zawartymi w jego syntetycznej monografii opublikowanej w 1944 r. Tym bardziej na uwagę zasługuje wiadomość o istnieniu w zbiorach Muzeum Narodowego we Lwowie szklanego naczynia pochodzącego z kryłoskich wykopalisk Pasternaka. Informacje zamieszczone w starszych opracowaniach wskazują, iż egzemplarz nie powinien przetrwać do czasów współczesnych. Czy jednak zachował się w całości, a może fragmentarycznie, przechowywany wraz z metryczką? Najważniejszymi zadaniami na przyszłość jest więc weryfikacja tej wzmianki, zapoznanie się z przedmiotem i ustalenie, jakie naczynie znajdujące się w muzeum we Lwowie zidentyfikowano jako znalezione w soborze w Kryłosie przez Ja. Pasternaka, oraz możliwie kompleksowe zbadanie zabytku.

Zgłębiając historię badań nad określonym problemem narażamy się na możliwość poznania „tylko” fragmentów przeszłości danej dyscypliny nauki i napisanie przyczynku do historii historiografii ${ }^{81}$. Zdarza się wszakże, że udaje się wyjść poza to minimum i m.in. odpowiedzieć na pytanie, kto, kiedy i na podstawie których źródeł jako pierwszy wyraził powszechnie znany pogląd bądź sformułował hipotezę ${ }^{82}$. Co udało się ustalić tym razem?

Podobieństwo dna kryłoskiego pucharka do den szklanych naczyń znalezionych prawdopodobnie w Kijowie w latach 1936-1937, których fotografię opublikował M.K. Kargier, staje się bardziej zrozumiałe, gdy wiemy, że sam Ja. Pasternak zwrócił uwagę, iż w obrębie posesji Petrows'kiego w Kijowie znaleziono liczne fragmenty takich ,szklanek”, jak ta z soboru w Kry-

81 Cetwiński M. 2018, s. 32.

${ }^{82}$ Por. np.: Kollinger K. 2018. 
łosie. W literaturze przedmiotu jednak nie odnotowano tego faktu. Jest to zresztą jedyna wskazówka przekazana nam przez Pasternaka sugerująca możliwy kształt dna pucharka z Kryłosu. Przydatne są również informacje, że na terenie wspomnianej działki prowadzono wykopaliska w tym właśnie okresie (1936-1937). Niestety znamienne jest bezkrytyczne przywoływanie lakonicznej wzmianki B.A. Rybakowa o odkryciu ok. setki den od szklanych pucharków o cienkich i kruchych ściankach (takich, jak znaleziony w Kryłosie), dokonanym podczas jego wykopalisk w Wyszogrodzie pod Kijowem w 1935 r. Uznano je, jak można sądzić, za cenne dla dziejów staroruskiego szkła, tymczasem w literaturze brak szczegółów na ich temat, w tym m.in. dotyczących kontekstu znalezienia i ich chronologii. Zasadny wydaje się wniosek, że mogły być one częścią naczyń różnych typów bądź ich wariantów. Aktualna wiedza o kształcie czasz staroruskich pucharków, w literaturze przedmiotu określanych jako podobne do kryłoskiego, jest niepewna i zdominowana przez hipotetyczne rekonstrukcje ${ }^{83}$.

Prowadzone na Ukrainie i w Rosji kwerendy archiwalne i muzealne dostarczają nowych informacji na temat badań terenowych prowadzonych w pierwszej połowie XX w. Jeszcze kilkanaście lat temu część z zaprezentowanych powyżej ustaleń była nieznana. Dzięki tym pracom sukcesywnie udaje się pogłębiać wiedzę historyczną, w tym w zakresie informacji biograficznych i staroruskiej kultury materialnej. Wszelkie nowe dane dotyczące odkryć w Kryłosie i okolicach w latach 1934-1943 ${ }^{84}$, w Wyszogrodzie w latach 1934-193785, a także w Kijowie zarówno na początku XX w., jak i w czwartej dekadzie tegoż stulecia, mogą okazać się ważne nie tylko dla odtworzenia dziejów tego jednego naczynia szklanego. Warto też przypominać, że podążając śladami poprzedników trzeba próbować poznać i zrozumieć sposób, w jaki oni badali przeszłość i pisali o niej.

Adres Autora:

dr Karol Kollinger

Instytut Archeologii i Etnologii PAN

Al. Solidarności 105

00-140 Warszawa

karolkollinger@gmail.com

http://orcid.org/0000-0002-4362-8338

\section{BIBLIOGRAFIA}

\section{Źródla i opracowania opublikowane}

Âčmen'ov N., Molčanovs'kij Feodosìj. 1936. Novì arheologičnì rozkopki u Kiêvì, „Socìalìstičnij Kiïv", nr 7-8, s. 57-60.

${ }^{83}$ Inaczej jest w przypadku tzw. pucharków dzwonowatych, których znaleziska z terenu Polski datowane są obecnie głównie na XVII-XIX w. Ich stopki są tego samego rodzaju, jak w naczyniach z Rusi, omawianych w tym artykule. Dla części okazów możliwe było jednoznaczne określenie formy (na ten temat m.in.: Olczak J. 1997; Prusicka-Kołcon E. 2000; Siembora S. 2017, s. 49-52; Majorek M., Grupa D., Nowak M. 2018, s. $156-161$. W tych pracach także starsza literatura).

${ }^{84}$ Niedostępne pozostały publikacje: Ters'kij S. 2008; Romanûk T. 2018.

85 Wiadomo, że w Archiwum Naukowym Instytutu Archeologii NAN Ukrainy znajdują się dzienniki polowe i sprawozdania oraz szklane negatywy z wykopalisk w Wyszogrodzie z lat 1934-1937 (Kozûba V. 2011; Bỉbìkov D. 2016, s. 108 n.; Stanicìna G. 2017, s. 200; Kapustìn K.M. 2020). Niedostępna była jednak praca kandydacka pt. „Wyszogród i jego okolica w X-XIII w.”, na potrzeby której opracowano materiały m.in. wówczas pozyskane (Bibikov D. 2018). Natomiast z zapiski dotyczącej prac przeprowadzonych w Wyszogrodzie w 1934 r. dowiadujemy się, że już wtedy znaleziono liczne fragmenty szklanych naczyń (Rozkopi. 1935; por.: Kozûba V. 2011). 
Bandrìvs'kij Mikola. 2005. Rol' greko-katolic 'koï cerkvi u pìdgotovcì ta provedennì istoriko-arheologičnih doslidžen' pam 'âtok knâžogo Galiča, [w:] Ukraïns'kì zemlì časìv korolâ Danila Galic'kogo. Cerkva ì deržava. Stattì j materìali, red. V. Gaûk i in., L'vìv, s. 129-133.

Bandrìvs'kij Mikola. 2015. Mitropolit Andrej Šeptic'kij - mecenat zahidnoukrä̈ns'koï arheologï (za materialami spìvpracì z direktorom Muzêิ NTŠ Âroslavom Pasternakom), „Materìali ì doslìdžennâ z arheologiï Prikarpattâ ì Volinì”, t. 19, s. 93-99.

Bandrìvs'kij Mikola, Lukoms'kij Urìj, Sulik Roman. 1993. Z istorï doslidžennâ Uspens 'kogo Soboru $v$ Galiči (Vìdkrittâ pohovannâ galic'kogo knâzâ Âroslava Osmomisla), „Zapiski Naukovogo Tovaristva ìmenì T. Ševčenka", t. 225: Pracì ìstorično-fillosofs'koï sekcì, s. 393-405.

Baran Volodimir. 2016. İstoriâ arheologičnih doslidžen' davn'ogo Galiča (seredina XIX-kinec' XX st.), „Ukraïnoznavstvo”, nr 1 (58), s. 171-190.

Belâêva Svitlana, Kalûk O. 1989. T. M. Movčanivs 'kij. Storìnki naukovoï bìografï (Do 90-rìččâ z dnâ narodžennâ), „Arheologíâ”, nr 2, s. 125-130.

Bezborodov Mihail Aleksandrovič. 1956. Steklodelie v Drevnej Rusi, Minsk.

Bỉbìkov Dmitro. 2016. Višgorods 'ka cerkva-mavzolej svâtih Borisa i Gliba. Pidsumki doslidžen' ta novi danì, „Arheologíâ", nr 4, s. 106-120.

Bỉbikov Dmitro. 2018. Višgorod ta jogo okruga v X-XIII st., Kiïv (Praca kandydacka napisana pod kierunkiem Andrìja Petrauskasa).

Bogusevič Volodimir Andrijovič. 1954. Masterskie XI v. po izgotovleniû stekla i smal'ty v Kieve, „Kratkie soobŝeniâ Instituta arheologii AN USSR”, t. 3, s. 14-20.

Cetwiński Marek. 2017. Drogi i bezdroża dziejopisarstwa, Olsztyn.

Cetwiński Marek. 2018. Co daje lepsze korzyści — „stan badań” czy „, historia problemu”?, „Kwartalnik Historii Nauki i Techniki”, R. 63, nr 3, s. 27-33.

Chudzik Dominik. 2014. Chrześcijańska architektura sakralna Rusi Halickiej i Wotyńskiej (do końca panowania Daniela Romanowicza), Collectio Archaeologica Ressoviensis, t. 27, Rzeszów.

Dąbrowski Dariusz. 2002. Rodowód Romanowiczów książą halicko-wotyńskich, Biblioteka Genealogiczna, t. 6, Poznań-Wrocław.

Dąbrowski Dariusz. 2008. Genealogia Mścisławowiczów. Pierwsze pokolenie (do poczatku XIV wieku), Kraków.

Dekówna Maria. 1980. Szkło w Europie wczesnośredniowiecznej, Wrocław.

Dombrovskij Dariuš. 2015. Genealogiâ Mstislavičej. Pervye pokoleniâ (do načala XIV v.), wyd. popr. i uzup., tłum. i wstęp K. Eruzalimskij, O. Ostapčuk, Studiorum Slavicorum Orbis, t. 10, Sankt-Peterburg.

Dovženok Vasil' Ïosipovič. 1950. Oglâd arheologíčnogo vivčennâ drevn'ogo Višgoroda za 1934-1937 rr., „Arheologíâ”, t. III, s. 64-92.

Ëlšin Denis Dmitrievič. 2007. Raskopki Imperatorskoj Arheologičeskoj komissii v Kieve v 1908-1914 gg.: novye arhivnye materialy, „Vestnik Sankt-Petersburgskogo universiteta”, Seria 2: Istoriâ, z. 4, s. 226-230.

Ëlšin Denis Dmitrievič. 2009. Imperatorskaâ Arheologičeskaâ komissiâ i raskopki v Kieve 1908-1914 gg., [w:] Imperatorskaâ Arheologičeskaâ Komissiâ (1859-1917): K 150-letiû so dnâ osnovaniâ. U istokov otečestvennoj arheologii i ohrany kul'turnogo naslediâ, red. A.E. Musin, E.N. Nosov, Sankt-Peterburg, s. 909-937.

Ëlšin Denis Dmitrievič, Melûh Ekaterina Andreevna, Hodakovskij Evgenij Valentinovič. 2015. Dmitrij Vasil'evič Mileev (1878-1914). Arhitekturnaâ arheologiâ i restavraciâ v Rossii v načale XX veka, Sankt-Peterburg.

Galibin Valentin Aleksandrovič. 2001. Sostav stekla kak arheologičeskij istočnik, Archaeologica Petropolitana, t. 11, Sankt-Peterburg.

Gavrilûk Oleksandr. 2010. Pidtrimka mitropolitom Andreêm Šeptic'kim pam 'âtkoohoronnoï diâl'nostì na zahidnoukraïns 'kih zemlâh y 1920-1930-h rokah, ,İstoričnij arhìv”, t. 5, s. 14-17.

Golembjovs'ka-Tobìaš Aneta, Dombrovs'kij Dariuš. 2019. Drakon Uspenskogo Soboru v Galičì z pol'skoï doslidnic 'koï perspektivi, „Galič. Zbìrnik naukovih prac'”, t. 4, s. 27-63.

Golovata Larisa. 2013. Ukraïns'kij legal'nij vidavničij ruh Central'no-Shidnoï Êvropi, 1939-1945, Kiïv-L'vìv. 
Golovko Oleksandr. 2009. Ostannì pohid knâzâ Romana Mstislaviča u džerelah ta istoričnìj dumcì, „Ukraïns'skij ìstoričnij žurnal”, nr 4, s. 28-47.

Golovko Oleksandr. 2017. Knâz' Mstislav Mstislavič "Udatnij» ì jogo doba, Kam’ânec'-Podil's'kij.

Gončarov Volodimir Kirilovič. 1955. Arheologični doslidžennâ drevn'ogo Galiča u 1951 r., „Arheologičnì pam'âtki URSR”, t. V, s. 22-31.

Gončarov Volodimir Kirilovič. 1956. Drevnij Galič, „Vìsnik Akademiï Nauk URSR”, R. XXVII, nr 1 (230), s. 61-67.

Gorbenko Sergìj. 1996. Aroslav Osmomisl. Rekonstrukciâ antropologična ta istorična, L'vìvVinniki.

Gribanova Nataliâ. 1996. "Vtračene» džerelo pro arheologičnì doslidžennâ 1908-1914 rr., [w:] Cerkva Bogorodicì Desâtinna v Kiêvi. Do 1000-littâ osvâčennâ, red. P. Toločko, Kiïv, s. 24-28.

Hojnovskij Iosif Adamovič. 1893. Raskopki velikoknâžeskago dvora drevnâgo grada Kìeva, proizvedennyâ vesnoû 1892 goda, Kìev".

Hryciuk Grzegorz. 1995. Prasa ukraińska i ukraińskojęzyczna w Galicji Wschodniej w latach 1939-1944, „Dzieje Najnowsze”, R. XXVII, nr 3, s. 47-66.

Hvojka Vikentij Vâceslavovič. 1913. Drevnie obitateli srednâgo Pridneprov'â $i$ ih" kul'tura v" doistoričeskiâ vremena (po raskopkam"), Kìev".

Ipat'evskaâ lìtopis'. 1908. Ipat'evskaâ litopis', wyd. A.A. Šahmatov, Polnoe Sobranìe Russkih" Litopisej, t. 2, wyd. 2, S.-Peterburg".

Kapustìn Kirilo Mikolajovič. 2020. Doslìžennâ Višgoroda u 1936 r., „Arheologîa ì davnâ ìstoriâ Ukraïni”, z. 1 (34), s. 132-151.

Karger Mihail Konstantinovič. 1940. K voprosu o Kieve v VIII-IXvv., „Kratkie soobŝeniâ o dokladah i polevyh issledovaniâh Instituta istorii material'noj kul'tury AN SSSR", t. VI, s. 61-66.

Karger Mihail Konstantinovič. 1952. Rozkopki na sadibi Kì̀vs 'kogo istoričnogo muzêu, „Arheologì̌nì pam'âtki URSR", t. III, s. 5-13.

Karger Mihail Konstantinovič. 1958. Drevnij Kiev. Očerki po istorii material'noj kul'tury drevnerusskogo goroda, t. 1, Moskva-Leningrad.

Kolesnikova Viktoriâ, Pavlenko Sergìj. 2017. «... mö̈m osobistym bažannâm $\hat{e}-$ ne porivati z naukovo-doslidnô̂ pracêิ ...». Narisi žittâ F.A. Kozubovs'kogo, „Arheologiâ ì davnâ ìstoriâ Ukraïni", z. 4 (25), s. 11-55.

Kollinger Karol. 2018. O znaczeniu archeologicznego kontekstu znalezisk także w badaniach historyków w związu z nowszymi hipotezami na temat atrybucji tzw. brakteatów tamańskich, „Archeologia Polski”, t. 63, s. 159-174.

Korzuhina Gali Fëdorovna. 1956. Novye dannye o raskopkah V. V. Hvojko na usad'be Petrovskogo $v$ Kieve, „Sovetskaâ arheologiâ”, t. XXV, s. 318-342.

Kostik Marìâ. 2013. Arroslav Osmomisl, İvano-Frankìvs'k.

Kostruba Teofil'. 1939. Hto osnovnik katedri v Galiči?, „Literaturno-naukovij dodatok Novogo času”, R. III, nr 17 (80): 24 kvìtnâ, s. III.

Kotlâr Mikola. 1996. İstorîa Ukrä̈ni v osobah. Davn'orus 'ka deržava, Kiïv.

Kotlâr Mikola. 2002. Danilo Galic'kij. Biografičnij naris, Kiïv.

Kozûba Vìtalìj. 2005. Doslidžennâ sadibi Desâtinnoï cerkvi u Kiêvì v 1908-1914 rr. (za materìalami sodennikiv D. V. Milêêva), „Ruthenica”, t. 4, s. 169-214.

Kozûba Vìtalì. 2006. Komentarì do rozdilu «Rozkopki v sadibì M. M. Petrovs 'kogo u Kiêvì, [w:] Doslìžennâ tripil'skoï civilizaciï u naukovì spadŝini arheologa Vikentiâ Hvojki, cz. 1: Perekladi naukovih prac' ta komentari, Kiïv, s. 186-189.

Kozûba Vìtalìj. 2010. Fotografii ta malûnki rozkopok V.V. Hvojki 1907-1908 rr. v sadibì M.M. Petrovs 'kogo u Kiêvì, [w:] Naukovo-doslidnic 'ka ta prosvitnic' 'ka diâl'nist' Vikentiâ Hvojki. Do 160-riččâ z dnâ narodžennâ. Materiali naukovo-praktičnoï konferencï̈ s. Halep'â, 19 lûtogo 2010 roku, Tripillâ, s. 59-78.

Kozûba Vìtalìj. 2011. Višgorods'ka arheologična ekspediciâ 1934 r. (za materìalami Naukovogo arhivu İnstitutu arheologï NANU), [w:] Starožitnostì Višgorodŝini. Zbirka tez, dopovidej 
ì povidomlen' 16-ö̈ naukovo-praktičnoï konferencï prisvâčenoï «Dnû pam'âtì Âroslava Mudrogo», 27-28 travnâ 2010 r., m. Višgorod, red. A.M. Plotnikova, Višgorod, s. 79-125.

Kozûba Vìtalìj. 2014. Doslìžennâ 1909-1910 rokiv Dmitra Milêêva hramu XI stolittâ v mitropoličomu sadu Sofï Kï̈vs'koï (za materialami naukovogo arhìu Institutu istorï materìal'nö̈ kul'turi u Sankt-Peterburzi), „Opus mixtum”, nr 2, s. 71-86.

Kozûba Vìtalìj. 2015. Doslìžennâ Desâtinnoï cerkvi i prilegloï teritorï u 1936-1939 rokah (korotkij oglâd negativìv rozkopok z Naukovogo arhìvu İA NAN Ukraïni), „Opus mixtum”, nr 3, s. $27-36$.

Kozûba Vitalì. 2018. «Shidnij» palac u davn'omu Kiêvì: novij poglâd na vìdomu pam 'âtku, „Opus mixtum", nr 6, s. 27-40.

Kubìjovič Volodimir. 1985. Menì 85, Mûnhen.

Lâska Vìtalìj. 2008. Planuval'na struktura Galiča XI-XIII st.: istoriâ doslidžen', „Materìali ì doslìdžennâ z arheologiï Prikarpattâ ì Volinì", t. 12, s. 467-476.

Majorek Magdalena, Grupa Dawid, Nowak Marcin. 2018. Wyroby szklane z badań archeologicznych w Płonkowie, [w:] Historia kościoła św. Oswalda w Płonkowie, t. II, red. M. Grupa, K. Jarzęcki, W. Nowosad, Płonkowo, s. 155-166.

Matwijów Maciej. 2015. (rec.:) Larisa Golovata, Ukraïns'kij legal'nij vidavničij ruh Central'no-Shidnö̈ Êvropi 1939-1945, Kï̈v-L'vìv: Vidavnictvo Noulidž 2013, 580 s. ISBN 978-617-579729-7, „Roczniki Biblioteczne”, R. LIX, s. 177-183.

Mel'nik Viktor, Bornâk Ulâna. 2019. Novì danì do istoriï, tehnologï pobudovi ta mistec'kogo ozdoblennâ Uspens 'kogo Soboru v knâžomu Galičì, „Knâža doba: ìstorîa ì kul'tura”, t. 13, s. $99-105$.

Olczak Jerzy. 1997. Domniemana funkcja liturgiczna i pochodzenie szklanych pucharków dzwonowatych z XVII-XVIII wieku na terenie Polski, [w:] Studia z archeologii i historii dedykowane Jerzemu Kruppému, Archaeologia Historica Polona, t. 5, red. J. Olczak, Toruń, s. 223-235.

Omel'čuk Bogdan. 2016. Zahidnij vektor kul'turno-ekonomičnih zv'âzkìv knâžogo Galiča, „Gìleâ: naukovij vìsnik", t. 108, s. 39-42.

Pan'kìvs'kij Kost'. 1965. Roki nimec 'koï okupaciï, N'û-Jork-Toronto.

Pasternak Âroslav. 1937a. Galic'ka katedra u Krilosì (timčasove zvidomlennâ z rozkopìv u 1936 i 1937 r.), L'vìv (Vìdbitka ìz Zapisok NTŠ, t. 154).

Pasternak Âroslav. 1937b. Odkrycie katedry halickiej, b.m.w. (Nadbitka z „Oriensu”, listopad-grudzień 1937).

Pasternak Âroslav. 1938. Katedra halicka w Kryłosie, „Biuletyn Historii Sztuki i Kultury”, R. VI, nr 1, s. 57-65.

Pasternak Âroslav. 1939. Peršì rozkopki na „Zolotomu Tocì” u Krilosì, „S'ogočasne j Minule. Vìsnik Ukraïnoznavstva", nr 1, s. 5-15.

Pasternak Âroslav. 1944. Starij Galič. Arheologično-ìstoričnì doslìdi u 1850-1943 rr., Krakìv-L'vìv.

Pasternak Âroslav. 1958. Starij Galič, „Mi ì Svìt. Ukraïns'kij magazin”, R. 9, cz. 51, s. 4-13.

Pasternak Âroslav. 1978. Moï zustrič̀i zi starovinô̂ (Zakinčennâ), „Ukraïns'kij ìstorik”, R. 15, nr 4(60), s. 64-82.

Pavlova Vìra. 2003. Kraêznavstvo v tvorčomu dorobku T. M. Movčanivs'kogo (arhìvnì ta muzejni džerela pro jogo dîal'nist'), „Studiï z arhìvnoï spravi ta dokumentoznavstva”, t. 10, s. 172-174.

Pekars'ka Lûdmila. 2016. Malovidomì skarbi z rozkopok Dmitra Milêêva 1909 roku na sadibi Desâtinnoï cerkvi v Kiêvi, „Opus mixtum”, nr 4, s. 166-177.

Peskova Anna Anisimovna. 2012. Maloizvestnaâ kollekciâ nahodok iz raskopok D. V. Mileeva v Kieve v 1908-1912 gg. (OAVEiS GČ, kollekciâ Nr 637), [w:] Pervye kamennye hramy Drevnej Rusi. Materialy arhitekturno-arheologičeskogo seminara 22-24 noâbrâ 2010 goda, red. D.D. Ëlšin, Trudy Gosudarstvennogo Èrmitaža, LXV, Sankt-Peterburg, s. 185-210.

Prusicka-Kołcon Ewa. 2000. Szklane pucharki dzwonowate z Zamościa od końca XVI wieku do końca XVII wieku, „Archeologia Polski Środkowowschodniej”, t. V, s. 230-239.

Raskopki. 1909. Raskopki v" Kievì v" 1909 godu (Svod" gazetnyh" izvìstij), „Izvìstiâ Imperatorskoj Arheologičeskoj Kommissì”, Pribavlenìe k" vypusku 32-mu (Hronika i biblìografîa, z. 16), s. $122-134$. 
Romanûk Taras. 2018. Aroslav Pasternak. Žittêpis včenogo, L'vìv.

Rozkopi. 1935. Rozkopi na teritoriï davn'ogo Višgoroda, „Naukovì zapiski Ìnstitutu ìstorii materìal'noï kul'turi", ks. 3-4, s. 103.

Rožankìvs'kij Vladimir Fedorovič. 1959. Ukraïns 'ke hudožnê sklo, Kiïv.

Rybakov Boris Aleksandrovič. 1948. Remeslo Drevnej Rusi, Moskva.

Ŝapova Ûliâ Leonidovna. 1963. Steklânnye izdeliâ drevnego Novgoroda, [w:] Trudy Novgorodskoj arheologičeskoj èkspedicii, t. III: Novye metody v arheologii, red. A.V. Arcihovskij, B.A. Kolčin, Materialy i issledovaniâ po arheologii SSSR, nr 117, Moskva, s. 104-163.

Ŝapova Ûliâ Leonidovna. 1972. Steklo Kievskoj Rusi, Moskva.

Ŝapova Ûliâ Leonidovna. 1997. Steklânnaâ posuda, [w:] Drevnââ Rus'. Byt i kul'tura, red. B.A. Kolčin, T.I. Makarova, Moskva, s. 31-33.

Ŝapova Ûliâ Leonidovna. 2008. Vizantijskoe steklo. Očerki istorii, wyd. 3, Moskva.

Šelkovnikov Bejbut Aleksandrovič. 1959. Steklo Kievskoj Rusi X-XIII vekov, „Vizantijskij vremennik", t. 16, s. 114-126.

Siembora Sebastian. 2017. Wyroby ze szkła odkryte w trakcie badań archeologicznych przy kościele w Górze Świętej Małgorzaty w pow. tęczyckim, „Acta Universitatis Lodziensis. Folia Archaeologica", nr 32, s. 47-63.

Sobranìe. 1902. Sobranìe B.I. i V.I. Hanenko. Drevnosti Pridneprov'â, t. V: Èpoha slavânskâ̂ (VI$-X I I I$ v.), Kìev".

Šovkoplâs Ganna. 2000. Višgorod ì jogo zamovčuvanì doslidniki, „Arheologičnì doslìdžennâ v Ukraïnì 1994-1996 rokìv", s. 181-185.

Stanicìna Galina. 2017. , Skarbi na sklì”. Kolekciâ fotonegativìv z fondìv Naukovogo arhìvu İnstitutu arheologiï NAN Ukraïni, „Materìali ì doslìdžennâ z arheologiï Prikarpattâ ì Volinì”, t. 21, s. $198-213$.

Stolârova Ekaterina Karlenovna. 2015. O priznakah mestnogo proizvodstva stekla (na primere Drevnej Rusi), [w:] Steklo Vostočnoj Evropy s drevnosti do načala XX veka, red. P.G. Gajdukov, SanktPeterburg, s. 336-343.

Ters'kij Svâtoslav. 2008. Arheologičnì materiali z rozkopok Galiča u drugìj pol. XIX - peršìj pol. XX st. u fondah l'vivs 'kih muzeïv: problema katalogizacï, „Naukovì zapiski” (L'vìvs' kij ìstoričnij muzej), t. 12 , s. 8-21.

Ters'kij Svâtoslav, Omel'čuk Bogdan. 2014. Arheologičnì materìali Âroslava Pasternaka u muzejnih kolekciâh, „Historical and Cultural Studies”/,İstoriko-kul'turnì studiì”, t. 1, nr 1, s. 89-93.

Tomenčuk Bogdan. 1998. Pricerkovnì kladoviŝa knâžogo Galiča, [w:] Galič i Galic 'ka zemlâ. Zbirnik naukovih prac', red. P.P. Toločko i in., Kiïv-Galič, s. 127-132.

Tomenčuk Bogdan. 2006. Arheologiâ nekropolivv Galiča ì Galic'koï zemli. Oderžavlennâ. Hristiânizaciâ, İvano-Frankìvs'k.

Tomenčuk Bogdan. 2013. Čotiri knâžì dvori litopisnogo Galiča. Pidsumki arheologičnih doslidžen palacovih kompleksìv (1991-2012 rr.), „Arheologiâ ì davnâ ìstoriâ Ukraïni”, t. 11, s. 165-177.

Vojtovič Leontìj. 2006. Knâža doba: portreti eliti, Bìla Cerkva.

State and history of research on a glass goblet from the 2 nd half of the 12 th $\mathrm{c}$. found in a woman's grave in Krylos

The article presents the circumstances and context of finding a glass goblet in a woman's grave in the Orthodox cathedral in the village of Krylos (near Halych, now in Ukraine) in 1937 (fig. 1) and an attempt at reconstructing the shape of this find. In addition to an overview of research on this topic, the article analyses the line of argumentation reflected in the literature, the ways in which researchers used their predecessors' findings to create their own narratives and the sources that were explored in this process. 
The author concludes that it still impossible to identify with certainty either the woman in whose grave the goblet had been found or the man buried close to her in a sarcophagus (Yaroslav Osmomysl?). The dating of the goblet to the 12th c. is generally not questioned. The shape of the vessel was reconstructed on the basis of the synthetic monograph Staryy Halych from 1944. For this reconstruction, it was assumed that the lower part of the vessel resembled in shape the bottoms of glass vessels excavated in Vyshhorod near Kiev in 1935, and probably in Kiev itself in 1936-1937. A similarity of the Krylos goblet to the Kiev finds had already been noted by its discoverer Yaroslav Pasternak, but this fact was overlooked in later literature. The finds from Vyshhorod were first noted by Boris A. Rybakov, whose laconic mention in the 1948 study Remeslo drevney Rusi was cited quite uncritically by later researchers. However, publications lacked details on those items, especially on their dating and the context of their finding.

According to an newer article by a Ukrainian researchers (2014), the glass vessel from the grave in Krylos is now in the collection of the National Museum in Lviv.

Research that is currently being done in Ukrainian and Russian archives and museums reveals new and new data on excavations carried out in the first half of the 20th c., which may prove very valuable in describing the history of the single vessel focused on in this article as well as in exploring a wide range of other topics.

Proofread by

Izabela Szymańska 